\title{
Effect of Bunch Removal on Grape Composition and Wine Quality of Vitis vinifera L. cv. Chardonnay
}

\author{
D. van Schalkwyk ${ }^{1}$, J.J. Hunter ${ }^{1}$ and J.J. Venter ${ }^{2}$
}

1) Nietvoorbij Institute for Viticulture and Oenology, Agricultural Research Council, Private Bag X5026, 7599 Stellenbosch, South Africa

2) Distillers Corp. LTD., P.O. Box 184, 7599 Stellenbosch, South Africa

Submitted for publication: May 1995

Accepted for publication: October 1995

Key words: Vitis vinifera, bunch removal, grape composition, wine quality, Chardonnay

\begin{abstract}
To determine whether grape composition and wine quality of premium wine grape cultivars in South Africa would be improved when certain degrees of bunch removal are applied at a later stage than $14^{\circ} \mathrm{B}$ and when all treatments are harvested at approximately the same sugar content, one-third and two-thirds of the bunches of Chardonnay were removed at $17^{\circ} \mathrm{B}$ and $19^{\circ} \mathrm{B}$ in a field trial at Robertson for three consecutive seasons $(1990$ - 1993). In addition to these four treatments, a control treatment (no bunch removal) and a treatment where bunches were harvested on the sunny and shaded sides of the same canopy (without prior bunch removal) at approximately $21,5^{\circ} \mathrm{B}$ were also included in the study. The economic use of removed grapes was determined, whereas all factors, including additional labour costs, were taken into account to establish whether bunch removal is an economically viable practice. A maximum reduction in yield of $11,6 \mathrm{t} \mathrm{ha}^{-1}$ compared to that of the control was obtained when two-thirds of the bunches were removed at $19^{\circ} \mathrm{B}$. No measurable compensation in berry mass occurred when bunches were removed at $17^{\circ} \mathrm{B}$ and $19^{\circ} \mathrm{B}$. Grapes removed at $17^{\circ} \mathrm{B}$ and $19^{\circ} \mathrm{B}$ were suitable for the making of distilled and sparkling wine or for use in wine blends and thus contributed to the total income of the vineyard. Bunch removal did not improve must and wine composition. Few differences in the concentrations of individual sugar and organic acids in the grapes, and volatile acid, alcohol and ester compounds in the wines were obtained. Wine of treatments where bunches were removed tended to be of lower quality. No improvement in wine quality was found with differential harvesting on the sunny and shaded sides of the canopy. Bunch removal was labour intensive and not economically viable.
\end{abstract}

It is widely believed by winemakers that high-yielding vines produce lower-quality wines. As a result of this, cultivars in South Africa are grouped into different wine quality categories according to production levels in the different regions.

The normal way of regulating the yield of a vineyard is application of different bud loads. However different degrees of bunch removal on high-yielding vines are also commonly recommended to reduce the yield of a cultivar within certain limits believed to be necessary for good wine production. Morando et al. (1991) showed that bunch thinning alone could not compensate for errors in or misapplication of other viticultural practices. Although chemical bunch thinning is cheaper, manual thinning is recommended because it is a more accurate way of regulating the amount of crop to be removed (Looney, 1981b; Reynolds 1989a; Petegolli, 1991; Zamboni et al., 1991; Payan et al., 1993). Bunch removal proved to be successful in reducing the yield and improving fruit composition of cultivars that have the propensity to overcrop, reducing the incidence of bunch rot, ensuring consistent vine vigour and yields and improving winter hardiness by more sufficient wood maturation in regions that are subjected to frost (Bravdo et al., 1993; Kliewer et al., 1983; Lott \& Emig, 1985; Reynolds et al., 1986; Bavaresco et al., 1991).

Extensive research examining thinning and bunch removal at various stages from pre-bloom to post-véraison has already been done and is still being done to determine whether crop reduction is an economically viable practice to improve wine quality of high yielding premium cultivars. Depending on the severity of bunch removal, yield were effectively reduced when bunch removal was applied during the period from before bloom until véraison (Looney \& Wood, 1977; Looney, 1981 b; Bravdo et al., 1984; Lott \& Emig, 1985; Bavaresco et al, 1991; Van Schalkwyk \& De Villiers, 1992a). However, when bunches were removed before veraison, it was reported that the vines compensated by means of an increase in the number of berries set as well as, berry and bunch mass, resulting in a smaller reduction in yields (Kliewer et al., 1983; Sépulveda et al., 1984; Murisier et al., 1986; Van Schalkwyk \& De Villiers, 1992b). Almost total yield compensation occurs when bunch removal is applied on cultivars with large clusters during pre-bloom or bloom, whereas cultivars with small bunches compensate to a lessor extent. However, compensation, and thus reduction in yield, is reduced when bunch removal is delayed until after berry set. Berry mass often increases when bunch removal is applied after berry set until véraison. Maximum crop reduction is obtained when bunches are removed after véraison as berry set has been completed by this stage and cell division and growth ended (Fisher et al., 1977; Di Collalto et al., 1991; Van Schalkwyk et al., 1995).

When bunch removal was applied in high-yielding vineyards, it normally induced earlier ripening of the grapes (Valentini et al., 1991), whereas overcropping tended to delay ripening (Cawthon et al., 1984; Murisier et al., 1986). Bunch removal reduced yield and generally changed grape composition by means of an increase in 
sugar content and $\mathrm{pH}$ and decrease in total acids (Wolpert et al., 1983; Reynolds, 1989a; Morando et al., 1991; Zironi et al., 1993). According to Sinton et al. (1978) there is a linear correlation between crop level and several of the juice components. Ough \& Nagaoka (1984), however, reported that bunch removal had a minimal effect on ripening and must composition.

Many investigators found that bunch removal improved the wine quality of different cultivars (Carbonneau et al., 1977; Bravdo et al., 1984; Ough \& Nagaoka, 1984; Lott \& Emig, 1985; Grigolli, 1989; Di Collalto et al., 1991; Ubigli, 1991). Wines made from the thinned treatments tended to have more intense varietal character and were of superior quality compared to the control where no bunches were removed. However, some researchers found that bunch removal had no significant effect on wine quality when applied on vines that are not overcropped (Reynolds, 1989b; Van Schalkwyk \& De Villiers, 1992b). Ough \& Nagaoka (1984) also warn that the wine quality improvement that might be gained by bunch removal should be carefully weighed against the loss in tonnage delivered to the winery. The effect of bunch removal on grape composition and wine quality is therefore still a controversial question.

Crop reduction is generally recommended in vineyards where overcropping might occur. However, in South Africa it is frequently recommended by some extension officers and advisers to improve wine quality from high-yielding premium vineyards. It is important to note that in most bunch removal trials where higher sugar and $\mathrm{pH}$ levels and lower total acid concentrations of the thinned treatments were found, all treatments were harvested on the same day. Although grapes from the treatments that were thinned matured faster than those of the controls, it is possible that the control grapes could reach the same sugar content at a later stage and thus be equal in must composition, if not better. It is therefore technically incorrect to conclude that crop reduction improves wine quality when all treatments were not harvested at the same sugar content.

Grapes which are removed prior to $14^{\circ} \mathrm{B}$ are a financial loss to the producer. The objective of this trial was, firstly, to determine whether grape composition and wine quality would be improved when certain degrees of bunch removal are applied at a later stage than $14^{\circ} \mathrm{B}$ and when all treatments are harvested at approximately the same sugar content. Secondly, the aim was to determine whether the grapes removed during bunch removal could be used economically and, thirdly, whether bunch removal is an economically viable practice when all factors, including additional labour costs, are taken into account.

\section{MATERIALS AND METHODS}

Experimental vineyard: A Chardonnay (clone CY
268) vineyard, grafted onto Richter 110 (clone RQ 28), and spaced $2,75 \mathrm{~m} \times 1,2 \mathrm{~m}$, was used. The soil was classified as a Sterkspruit soil, according to the system of MacVicar et al. (1991). It can be described as a reddish sandy clayloam soil which represents a relatively high percentage of the soils in the Robertson Breede River region.

Vines were trained onto a Six-Wire Extended Perold System (Booysen et al., 1992) with movable canopy wires. The vines were intensively irrigated by means of microjets. Irrigation was scheduled according to tensiometers in such a way that none of the vines was subjected to water stress during any stage of the growth season. All the vines were pruned to 10 two-bud spurs and suckered to leave only the bearing shoots on the spurs. Between bloom and berry set leaves were evenly removed, where necessary, right through the canopy in the bunch zone, leaving approximately three layers of leaves (Hunter, 1992; Hunter et al., 1995). At pea size vines were topped $30 \mathrm{~cm}$ above the top wire. A standard disease and pest control programme against mealy bug, leaf hoper, erinose, oidium, downy mildew and botrytis rot was applied.

Treatments and viticultural determinations: The trial with six treatments was established during 1990 using a randomised block design with four replicates, each plot comprising 24 vines. One-third and two-thirds of the bunches were removed at random over the whole vine at $17^{\circ} \mathrm{B}$ and $19^{\circ} \mathrm{B}$. In addition to these four treatments, a control where no bunches were removed, and a treatment (also without prior bunch removal) where the bunches were harvested separately on the sunny and shaded sides of the same canopy at approximately $21,5^{\circ} \mathrm{B}$, were also included in the study. The experiment was conducted for three consecutive seasons (19901993). The total yield, berry mass, cane mass, budding percentage and bud fertility (number of bunches per bud allocated during pruning) were determined annually. The removed grapes were analysed for total soluble solids, titratable acidity and $\mathrm{pH}$.

Grape analyses: Individual sugars (glucose and fructose) and organic acids (tartaric acid, malic acid and citric acid) were extracted from ripe, freeze-dried grapes and analysed by HPLC according to the methods described by Hunter, Visser \& De Villiers (1991).

Must analyses: During the last season of the trial, must were analysed for free amino-nitrogen content by means of an automated ninhydrin method using ammonium sulphate as reference standard (Vos et al., 1978). Total soluble solids, titratable acidity and $\mathrm{pH}$ of the must were also determined before and after skin contact.

Winemaking: Grapes of all treatments were harvested at approximately $21-22^{\circ} \mathrm{B}$ and pre-cooled to below $10^{\circ} \mathrm{C}$ before being crushed and left on the skins for four hours. Thereafter, the grapes were pressed and must fer- 
mented to below $4 \mathrm{~g} /{ }^{-1}$ sugar following standard Nietvoorbij winemaking procedures. After bottling, wine was stored at $18^{\circ} \mathrm{C}$ until analyses.

Wine chemical analyses: Wines from the last two seasons were analysed approximately six months after fermentation was completed. Volatile acids, higher alcohols and esters were extracted from wines (Marais \& Houtman, 1979) and determined gas chromatographically according to the following conditions:
Integrator
Column

Gas chromatograph

: Varian Vista 6000

: Spectra-Physics SP 4290

: $30 \mathrm{~m}$ x 0,32 mm J \& W

Scientific fused silica

capillary column with

DB-Wax liquid phase

and $0,25 \mathrm{~m}$ film thickness.

Injection temperature $\quad: 200^{\circ} \mathrm{C}$

Detector (FID) temperature : $250^{\circ} \mathrm{C}$

Temperature Program $: 37^{\circ} \mathrm{C}$, held for $6 \mathrm{~min}$.

: $37^{\circ} \mathrm{C}$ to $65^{\circ} \mathrm{C}$ at $5^{\circ} \mathrm{C} / \mathrm{min}$.,

held for $1 \mathrm{~min}$.

: $65^{\circ} \mathrm{C}$ to $150^{\circ} \mathrm{C}$ at $6^{\circ} \mathrm{C} / \mathrm{min}$.,

held for $1 \mathrm{~min}$.

: $150^{\circ} \mathrm{C}$ to $190^{\circ} \mathrm{C}$ at $6,5^{\circ} \mathrm{C} / \mathrm{min}$., held for $20 \mathrm{~min}$.

Carrier gas

: Helium

For calibration purposes a standard synthetic wine was prepared with $12 \%$ ethanol. An internal standard of 4methyl-2-pentanol was used.

Wine sensory analyses: Wines of all three seasons were also sensorially evaluated for aroma character and overall wine quality by a trained panel consisting of 15 tasters six months after bottling. Experienced tasters who were able to identify the different descriptors were used. Tastings were done in a special tasting room. A ninepoint scale developed by Tromp and Conradie (1979) was used to determine cultivar character and overall wine quality.

Economic viability: Time studies for bunch removal and harvesting were done to determine the total costs involved in bunch removal. Economic projections, which included the use of the removed grapes for the making of different wine products, were also done to determine whether bunch removal is an economically viable practice. The potential income from the removed grapes and grapes harvested at maturity, calculated for the specific wine objective, was based on the mean minimum wine prices of the $\mathrm{KWV}^{*}$ over the three years of the trial. Potential gross income was calculated on the basis of the wine scores received and projected in accordance with the mean lowest and highest prices that were paid for Chardonnay during these three seasons.

Statistical analyses: An Anova analyses was performed on the viticultural data and the wine sensory data were statistically analysed using Friedmans non-parametric test (Siegel, 1959)

\section{RESULTS AND DISCUSSION}

Viticultural performance: Although manual bunch removal is an accurate method to ensure that the correct percentage of bunches is removed, it does not necessarily mean that yield at maturity is reduced in the same proportion (Fig. 1). It appears that some degree of compensation by the vines occurred after bunch removal. Although no significant differences in berry mass of the removed grapes were found between treatments, bunch masses of the treatment where $2 / 3$ of the bunches were removed at $19^{\circ} \mathrm{B}$ and those of the treatment harvested on the sunny side were lower than that of bunches removed at $17^{\circ} \mathrm{B}$ (Table 1 ).

Bunch removal at $17^{\circ} \mathrm{B}$ and $19^{\circ} \mathrm{B}$ advanced the harvesting date of the remaining grapes by $4-5$ days compared to those of control vines (Table 2). It is also evident that bunches situated on the shaded side of the canopy took longer to reach the same maturation level than the other treatments. When the mean berry mass at maturity (Table 2) is compared to that during bunch removal (Table 1). It appears that the vines did not compensate for the loss of bunches. It is possible that the smaller number of bunches per vine reduced the photosynthetic activity of the leaves because of a lower assimilate demand. Kaps \& Cahoon (1989) found that photosynthesis increased in response to greater assimilate demands when the crop level of potted and field-grown Seyval blanc vines per plant was increased. It is quite conceivable that the reverse may also happen. That may also explain why the mean bunch mass of the control was significantly higher than that of the bunch remove treatments (Table 2).

In contrast to previous findings, where bunch removal was applied at different phenological stages (Carbonneau et al. 1977; Fisher et al., 1977; Looney, 1981a; Looney, 1981b; Bravdo et al., 1984), bunch removal had no effect on shoot mass (Table 2). In this study a general decline in overall vegetative growth of all treatments was noted during the study period. It would appear as if the amount of carbohydrates (sucrose) which is canalised to the vegetative parts of the vines decreased when bunches were removed at $17^{\circ} \mathrm{B}$ or $19^{\circ} \mathrm{B}$. Budding percentage and bud fertility of the vines were not affected by the removal of bunches at either $17^{\circ} \mathrm{B}$ or $19^{\circ} \mathrm{B}$ (Table 2 ). However, an increase in bud fertility of all treatments was noted after the first year, whereafter it declined (data not shown).

Although bunch removal had no effect on the total yield (removed plus harvested) of Chardonnay during individual seasons, the mean total yields of the control and the treatment where $2 / 3$ of the bunches were removed at $17^{\circ} \mathrm{B}$, were significantly higher than those of

*KWV - Co-operative Wine Growers' Association of South Africa Ltd. 
TABLE 1

Mean characterisitics and must analyses of Chardonnay (clone CY 268) bunches removed at $17^{\circ} \mathrm{B}, 19^{\circ} \mathrm{B}$ and harvested on the sunny side of canopy at $21,5^{\circ} \mathrm{B}(1990-1993)$.

\begin{tabular}{|c|c|c|c|c|c|c|}
\hline & \multicolumn{5}{|c|}{ Treatments } & \multirow[b]{2}{*}{$\mathrm{D}(\mathrm{p} \leq 0,05)$} \\
\hline & $\begin{array}{c}1 / 3 \text { of bunches } \\
\text { removed } \\
\text { at } 17^{\circ} \mathrm{B}\end{array}$ & $\begin{array}{c}2 / 3 \text { of bunches } \\
\text { removed } \\
\text { at } 17^{\circ} \mathrm{B}\end{array}$ & $\begin{array}{c}1 / 3 \text { of bunches } \\
\text { removed } \\
\text { at } 19^{\circ} \mathrm{B}\end{array}$ & $\begin{array}{c}2 / 3 \text { of bunches } \\
\text { removed } \\
\text { at } 19^{\circ} \mathrm{B}\end{array}$ & $\begin{array}{c}\text { Grapes* } \\
\text { harvested on } \\
\text { sunny side } \\
\text { at } 21,5^{\circ} \mathrm{B}\end{array}$ & \\
\hline Date of bunch removal & $22 / 01$ & $22 / 01$ & $03 / 02$ & $02 / 02$ & $14 / 02$ & - \\
\hline Grapes removed $t$ ha $^{-1}$ & 5,2 & 10,4 & 6,5 & 8,1 & 6,5 & 1,8 \\
\hline Mass 100 berries $^{-1}(\mathrm{~g})$ & 110,0 & 118,2 & 112,5 & 109,1 & 112,5 & NS \\
\hline Bunch mass (g) & 161,4 & 161,3 & 153,9 & 139,6 & 139,5 & 17,8 \\
\hline Sugar $\left({ }^{\circ}\right.$ Brix $)$ & 17,3 & 17,2 & 19,4 & 19,1 & 21,7 & 0,7 \\
\hline Titrable acids $\mathrm{g} \mathrm{L}^{-1}$ & 10,5 & 10,6 & 8,3 & 8,3 & 7,2 & 0,8 \\
\hline $\mathrm{pH}$ & 2,95 & 2,93 & 3,14 & 3,12 & 3,79 & 0,09 \\
\hline
\end{tabular}

* Grapes were harvested separately on the sunny side of the canopy at $21,5^{\circ} \mathrm{B}$ of the treatment where differential harvesting was applied.

NS No significant differences.

TABLE 2

Mean effect of bunch removal during different stages of ripening on the viticultural performance and must composition (before skin contact) of Chardonnay (clone CY 268) (1990 - 1993).

\begin{tabular}{|c|c|c|c|c|c|c|c|c|}
\hline \multirow[b]{2}{*}{ Parameters } & \multicolumn{7}{|c|}{ Treatments } & \multirow[b]{2}{*}{$(\mathrm{p} \leq 0,05)$} \\
\hline & $\begin{array}{c}\text { Control } \\
\text { (no bunches } \\
\text { removed) }\end{array}$ & $\begin{array}{c}1 / 3 \text { of } \\
\text { bunches } \\
\text { removed } \\
\text { at } 17^{\circ} \mathrm{B}\end{array}$ & $\begin{array}{l}2 / 3 \text { of } \\
\text { bunches } \\
\text { removed } \\
\text { at } 17^{\circ} \mathrm{B}\end{array}$ & $\begin{array}{l}1 / 3 \text { of } \\
\text { bunches } \\
\text { removed } \\
\text { at } 19^{\circ} \mathrm{B}\end{array}$ & $\begin{array}{l}2 / 3 \text { of } \\
\text { bunches } \\
\text { removed } \\
\text { at } 19^{\circ} \mathrm{B}\end{array}$ & $\begin{array}{c}\text { Grapes } \\
\text { harvested } \\
\text { on sunny } \\
\text { side at } \\
21,5^{\circ} \mathrm{B}\end{array}$ & $\begin{array}{c}\text { Grapes } \\
\text { harvested } \\
\text { on shaded } \\
\text { side at } \\
21,5^{\circ} \mathrm{B}\end{array}$ & \\
\hline Date harvested & $19 / 02$ & $15 / 02$ & $14 / 02$ & $14 / 02$ & $15 / 02$ & $14 / 02$ & $21 / 02$ & - \\
\hline Sugar $\left({ }^{\circ}\right.$ Brix $)$ & 21,6 & 21,7 & 21,5 & 21,9 & 21,8 & 21,7 & 22,1 & NS \\
\hline Glucose: fructose & 1,1 & 1,1 & 1,1 & 1,1 & 1,1 & 1,1 & 1,1 & NS \\
\hline Titrable acids $\mathrm{g} \mathrm{L}^{-1}$ & 7,6 & 7,4 & 7,3 & 7,4 & 7,0 & 6,6 & 7,0 & 0,5 \\
\hline Tartaric: malic acid & 1,5 & 1,5 & 1,5 & 1,5 & 1,3 & 1,6 & 1,6 & NS \\
\hline Citric acid $\mathrm{mg} \mathrm{g} \mathrm{dm}^{-1 *}$ & 1,3 & 1,4 & 1,2 & 1,4 & 1,5 & 1,4 & 1,4 & 0,3 \\
\hline Free amino-nitrogen $\mathrm{mg} \mathrm{L}$ & 1623 & 1413 & 1290 & 1595 & 1533 & 1228 & 1345 & NS \\
\hline $\begin{array}{l}\text { Free amino-nitrogen: } \\
\text { sugar }\left({ }^{\circ} \mathrm{B}\right)\end{array}$ & 76,7 & 65,3 & 62,0 & 73,9 & 70,6 & 58,4 & 61,1 & NS \\
\hline $\mathrm{pH}$ & 3,46 & 3,51 & 3,48 & 3,48 & 3,51 & 3,69 & 3,47 & NS \\
\hline Cane mass t ha ${ }^{-1}$ & 2,7 & 2,6 & 2,6 & 2,3 & 2,6 & $* *$ & 2,3 & NS \\
\hline Bunch mass (g) & 156,0 & 135,2 & 132,5 & 127,1 & 130,9 & 139,5 & 124,1 & 16,2 \\
\hline 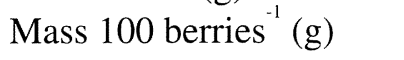 & 124,0 & 117,7 & 114,0 & 113,0 & 112,2 & 112,5 & 113,3 & NS \\
\hline
\end{tabular}

NS No significant differences.

* Only analysed during 1993 (dm =dry mass).

** The same vines were used for differential harvest on the sunny and shaded side of the canopy. As grapes from both were suitable for making wines of good quality, wines were also made from grapes harvested on the sunny side and statistically compared with wines from other treatments. 
the treatments where $2 / 3$ of the bunches were removed at $19^{\circ} \mathrm{B}$ and where grapes were harvested differentially (Fig.1). The latter two treatments and the treatment where $1 / 3$ of the bunches were removed at $19^{\circ} \mathrm{B}$ tended to have the lowest bunch mass (Table 2). The highest crop mass at maturity was harvested from the control and the treatment where $1 / 3$ of the bunches were removed at $17^{\circ} \mathrm{B}$. The biggest reduction in yield, $11,6 \mathrm{t}$ ha $^{-1}$ less than the control, was obtained when $2 / 3$ of the bunches were removed at $19^{\circ} \mathrm{B}$. Vines apparently yielded slightly less grapes on the sunny side of the canopy.

Must composition and wine performance: Must analyses showed that grapes removed at $17^{\circ} \mathrm{B}$ and $19^{\circ} \mathrm{B}$ were suitable for making distilled and sparkling wine or for use in wine blends (Table 1). Zironi et al., (1993) even found that grapes of Chardonnay removed at $12^{\circ} \mathrm{B}$ were suitable for the production of fermented juices with a low alcohol content, which can either be used as a pure beverage or mixed with other juices.

As all treatments were harvested at approximately $21,5^{\circ} \mathrm{B}$, few differences in must analyses were found at maturity (Table 2). It is evident that bunch removal had little effect on grape and must composition. The thorough canopy management practices, which created an uniform microclimate and well-exposed leaves and bunches, most probably contributed largely to the ability of the control vines to sufficiently ripen a much bigger crop. This was also found by others (Smart, 1984; et al., 1990).

Titratable acid and $\mathrm{pH}$ of the must of the bunch removal treatments were significantly affected (Table 3 ).
When must composition before and after skin contact is compared, it would appear as if a high percentage of the acids was lost during this process, which not only decreased the total acidity, but increased the $\mathrm{pH}$ of the must as well. It also seems as if the wine quality of these treatments tended to be lower (Table 4 ), the overall wine quality of the $2 / 3$ bunch removal treatment at $19^{\circ} \mathrm{B}$ being the lowest.

Sensory description of some specific aromas and the intensities of aroma nuances were also used to determine differences between wines (Fig. 2). Bunch removal apparently induced differences in wine aroma profiles.

Bunch removal also had a marked effect on the concentrations of some individual volatile alcohol, acid and ester compounds in the wines (Fig. 3). With few exception, concentrations of certain compounds (i-Amyl Alcohol, Ethyl Caproate, 2-Phenyl-Ethyl Acetate, 2Phenyl Ethanol \& Octanoic Acid) in control wines tended to be higher during some seasons (data not shown) and might have contributed to the higher quality tendency of the control wines (Table 2).

Economic viability: Time studies done during bunch removal and harvesting showed that bunch removal is a labour intensive practice, particularly when an accurate reduction in yield was to be obtained (Fig. 4).

Calculation of the potential gross income clearly shows that bunch removal of Chardonnay is not an economically viable practice under the conditions of the trial in the Robertson region (Fig. 5).

\section{TABLE 3}

Mean effect of degree of bunch removal at different stages during ripening on the must composition of Chardonnay (clone CY 268) after skin contact (1990-1993).

\begin{tabular}{|c|c|c|c|c|c|c|c|c|}
\hline \multirow[b]{2}{*}{ Parameters } & \multicolumn{7}{|c|}{ Treatments } & \multirow[b]{2}{*}{$\mathrm{D}(\mathrm{p} \leq 0,05)$} \\
\hline & $\begin{array}{c}\text { Control } \\
\text { (no bunches } \\
\text { removed) }\end{array}$ & $\begin{array}{l}1 / 3 \text { of } \\
\text { bunches } \\
\text { removed } \\
\text { at } 17^{\circ} \mathrm{B}\end{array}$ & $\begin{array}{c}2 / 3 \text { of } \\
\text { bunches } \\
\text { removed } \\
\text { at } 17^{\circ} \mathrm{B}\end{array}$ & $\begin{array}{c}1 / 3 \text { of } \\
\text { bunches } \\
\text { removed } \\
\text { at } 19^{\circ} \mathrm{B}\end{array}$ & $\begin{array}{l}2 / 3 \text { of } \\
\text { bunches } \\
\text { removed } \\
\text { at } 19^{\circ} \mathrm{B}\end{array}$ & $\begin{array}{c}\text { Grapes } \\
\text { harvested } \\
\text { on } \\
\text { sunny side } \\
\text { at } 21,5^{\circ} \mathrm{B}\end{array}$ & $\begin{array}{c}\text { Grapes } \\
\text { harvested } \\
\text { on shaded } \\
\text { side at } \\
21,5^{\circ} \mathrm{B}\end{array}$ & \\
\hline Sugar $\left({ }^{\circ} \mathrm{C}\right)$ Brix & 21,8 & 22,0 & 21,9 & 22,1 & 21,9 & 21,7 & 22,1 & NS \\
\hline Titrable acids $\mathrm{g} \mathrm{L}^{-1}$ & 7,5 & 6,9 & 6,7 & 6,3 & 6,7 & 6,7 & 5,1 & 1,0 \\
\hline Sugar:acid & 3,0 & 2,9 & 3,4 & 3,6 & 3,5 & 3,4 & 4,4 & 0,6 \\
\hline $\mathrm{pH}$ & 3,76 & 3,88 & 3,82 & 3,86 & 3,86 & 3,93 & 3,84 & 0,10 \\
\hline Free-run juice $(\%)$ & 32,7 & 33,4 & 35,1 & 33,1 & 32,0 & 35,0 & 32,6 & NS \\
\hline Wine less (\%) & 27,5 & 25,6 & 26,8 & 27,4 & 23,8 & 23,6 & 26,8 & NS \\
\hline
\end{tabular}

NS No significant differences.

* The same vines were used for differential harvest on the sunny and shaded sides of the canopy. As grapes from both were suitable for making wines of good quality, wines were also made from grapes harvested on the sunny side and statistically compared with wines from other treatments. 


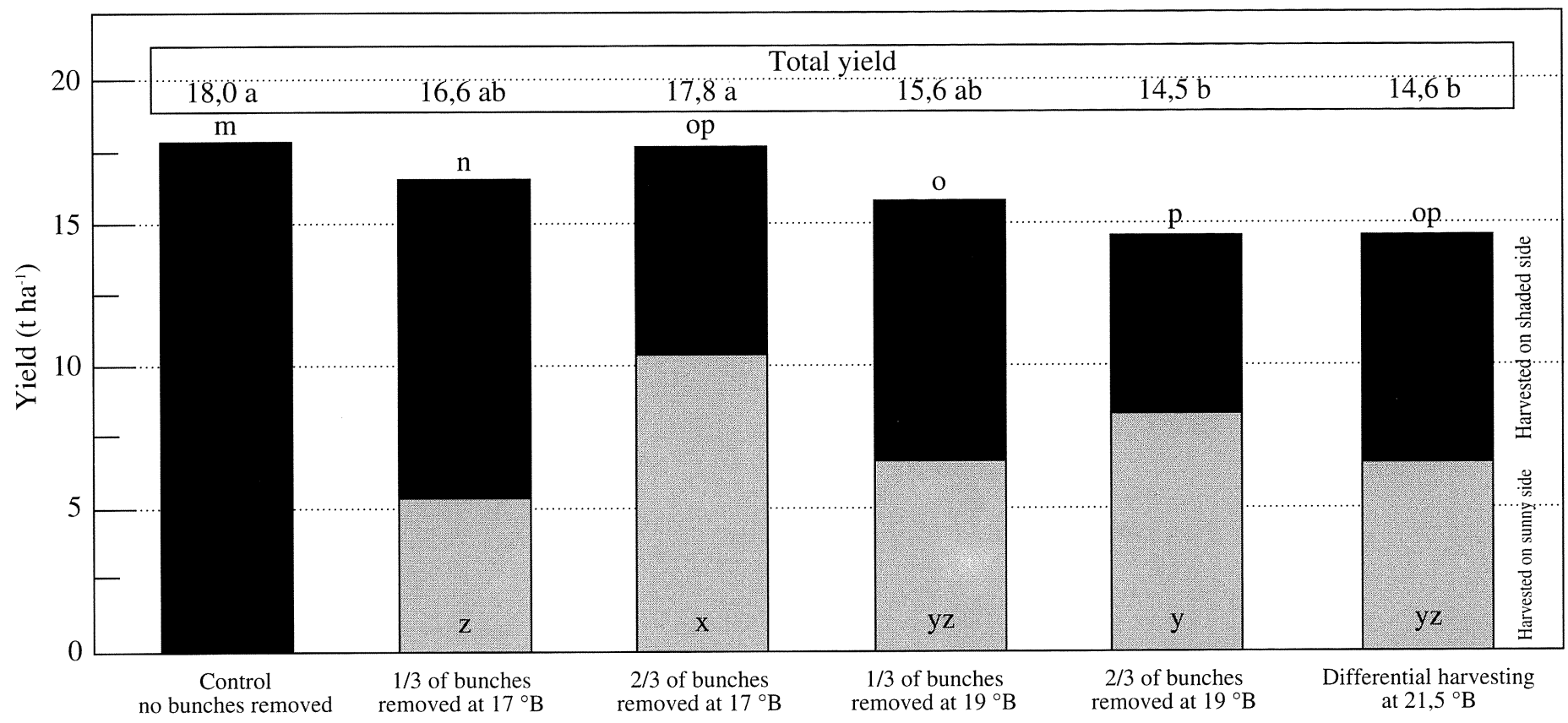

Degree and time of bunch removal

\section{Removed Harvested}

FIGURE 1

Mean effect of bunch removal at different stages of ripening on the yield of Chardonnay (clone CY 268) (1990-1993). Compounds with similar concentrations were grouped together. Bars designated by the same letter do not differ significantly $(\mathrm{p} \leq 0,05)$.

TABLE 4

Mean effect of degree of bunch removal at different stages during ripening on the wine composition and wine quality of Chardonnay (clone CY 268) (1990 -1993).

\begin{tabular}{|c|c|c|c|c|c|c|c|c|}
\hline \multirow[t]{2}{*}{ Parameters } & \multicolumn{7}{|c|}{ Treatments } & \multirow[b]{2}{*}{$\mathrm{D}(\mathrm{p} \leq 0,05)$} \\
\hline & $\begin{array}{l}\text { Control } \\
\text { (no bunches } \\
\text { removed) }\end{array}$ & $\begin{array}{c}1 / 3 \text { of } \\
\text { bunches } \\
\text { removed } \\
\text { at } 17^{\circ} \mathrm{B}\end{array}$ & $\begin{array}{l}2 / 3 \text { of } \\
\text { bunches } \\
\text { removed } \\
\text { at } 17^{\circ} \mathrm{B}\end{array}$ & $\begin{array}{c}1 / 3 \text { of } \\
\text { bunches } \\
\text { removed } \\
\text { at } 19^{\circ} \mathrm{B}\end{array}$ & $\begin{array}{l}2 / 3 \text { of } \\
\text { bunches } \\
\text { removed } \\
\text { at } 19^{\circ} \mathrm{B}\end{array}$ & $\begin{array}{c}\text { Grapes } \\
\text { harvested } \\
\text { on } \\
\text { sunny side } \\
\text { at } 21,5^{\circ} \mathrm{B}\end{array}$ & $\begin{array}{c}\text { Grapes } \\
\text { harvested } \\
\text { on shaded } \\
\text { side at } \\
21,5^{\circ} \mathrm{B}\end{array}$ & \\
\hline Alcohol (\% volume) & 12,8 & 13,2 & 13,0 & 13,3 & 13,1 & 12,4 & 13,1 & 0,5 \\
\hline Extract $\mathrm{g} \mathrm{L}^{-1}$ & 25,7 & 26,5 & 26,2 & 25,0 & 24,4 & 23,7 & 25,2 & 1,7 \\
\hline Volatile acid $\mathrm{g} \mathrm{L}^{-1}$ & 0,58 & 0,66 & 0,60 & 0,69 & 0,59 & 0,47 & 0,64 & 0,1 \\
\hline Sugar $\mathrm{g} \mathrm{L}^{-1}$ & 1,6 & 1,8 & 1,8 & 1,8 & 1,6 & 1,8 & 1,6 & NS \\
\hline Titrable acid $\mathrm{g} \mathrm{L}^{-1}$ & 5,7 & 6,0 & 6,0 & 5,7 & 5,4 & 5,5 & 5,2 & 0,4 \\
\hline $\mathrm{pH}$ & 3,77 & 3,83 & 3,83 & 3,85 & 3,72 & 3,80 & 3,92 & 0,12 \\
\hline Wine quality (\%) & 62,8 & 60,4 & 58,0 & 61,4 & 56,9 & 59,9 & 61,4 & 3,9 \\
\hline Cultivar character $(\%)$ & 64,5 & 63,6 & 61,1 & 61,8 & 61,6 & 63,9 & 63,8 & 2,3 \\
\hline
\end{tabular}

NS No significant differences.

* The same vines were used for differential harvest on the sunny and shaded sides of the canopy. As grapes from both were suitable for making wines of good quality, wines were also made from grapes harvested on the sunny side and statistically compared with wines from other treatments. 


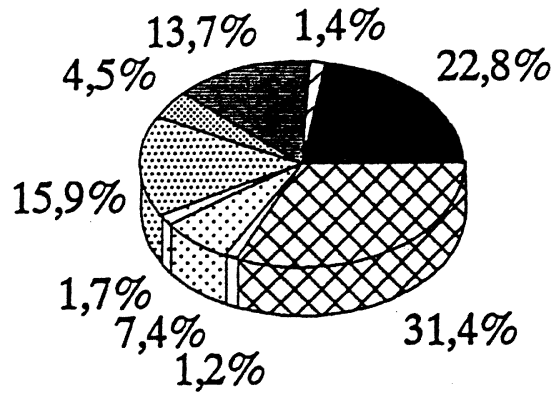

$1 / 3$ of bunches removed at $17^{\circ} \mathrm{B}$

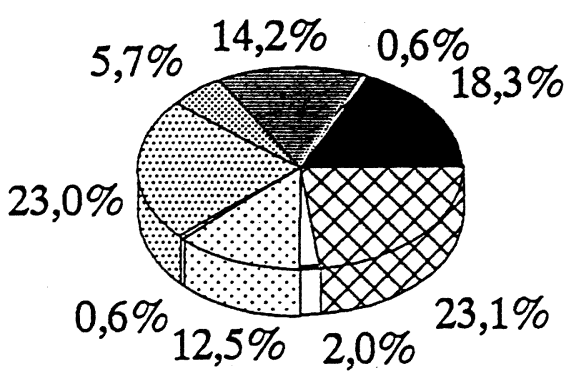

$1 / 3$ of bunches removed at $19{ }^{\circ} \mathrm{B}$

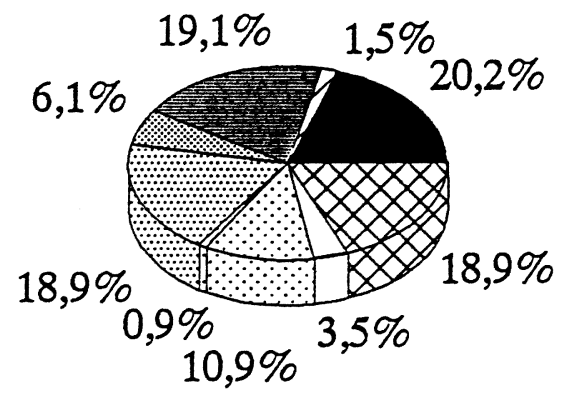

Grapes harvested on sunny side of canopy at $21,5^{\circ} \mathrm{B}$

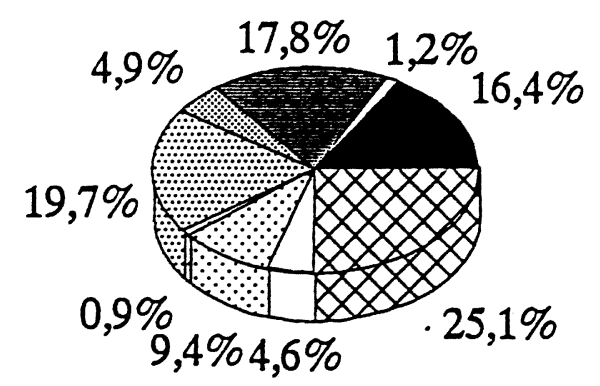

$2 / 3$ of bunches removed at $17^{\circ} \mathrm{B}$

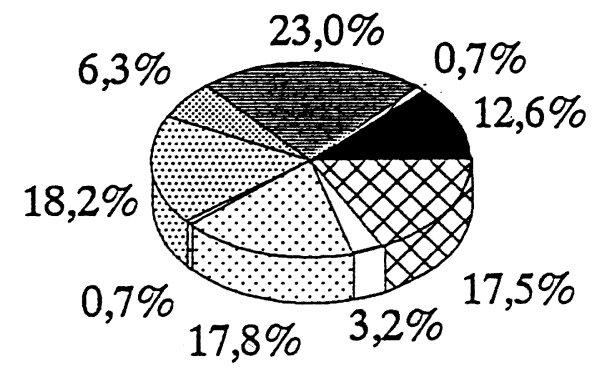

$2 / 3$ of bunches removed at $19^{\circ} \mathrm{B}$

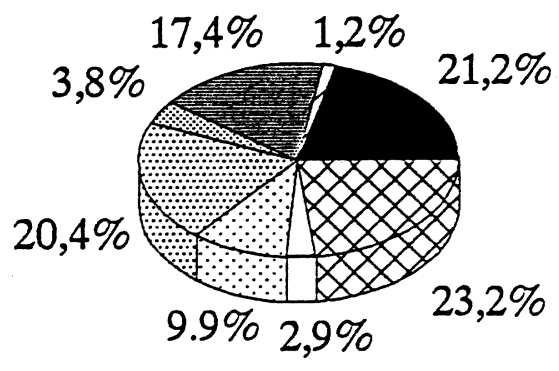

Grapes harvested on shaded side of canopy at $21,5^{\circ} \mathrm{B}$

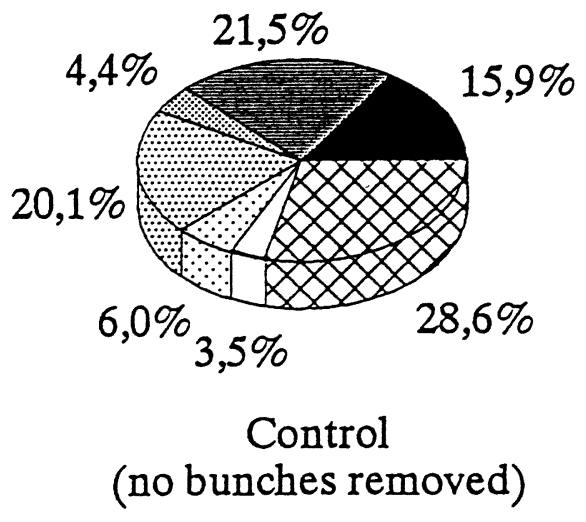

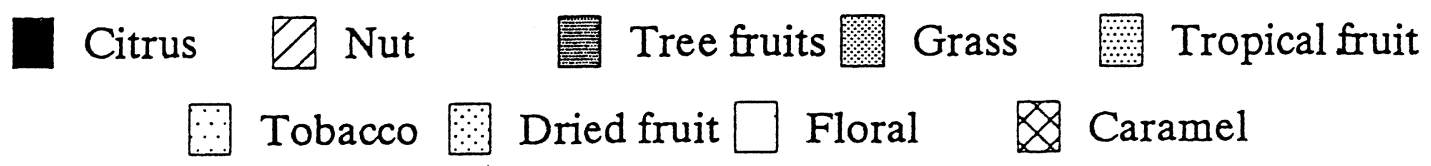

FIGURE 2

Mean effect of bunch removal on the percentage aroma distribution of the main aroma characteristics of Chardonnay (clone CY 268) wines (1990-1993). 


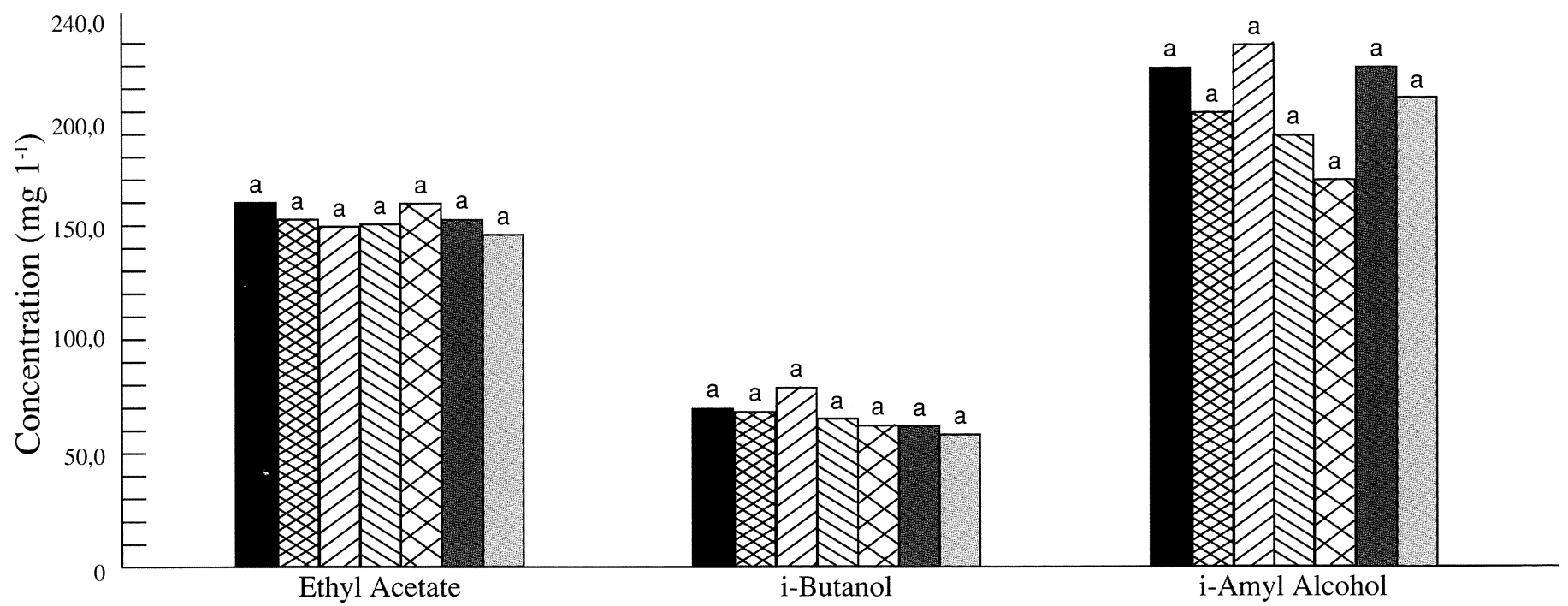

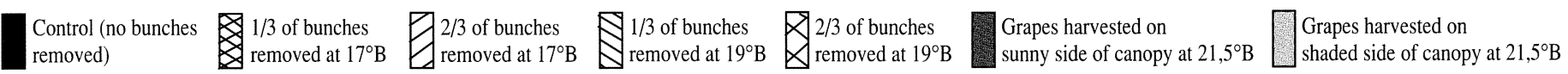

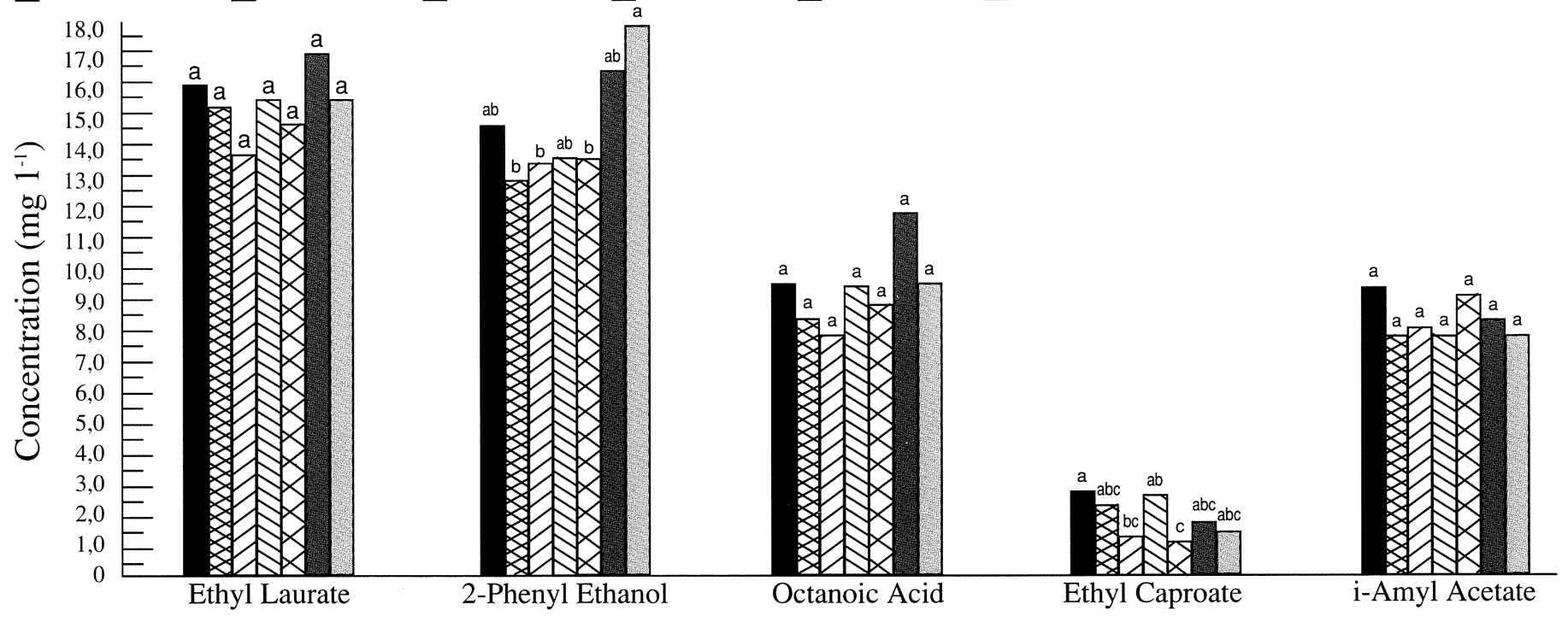

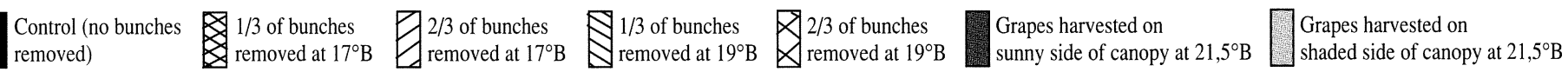

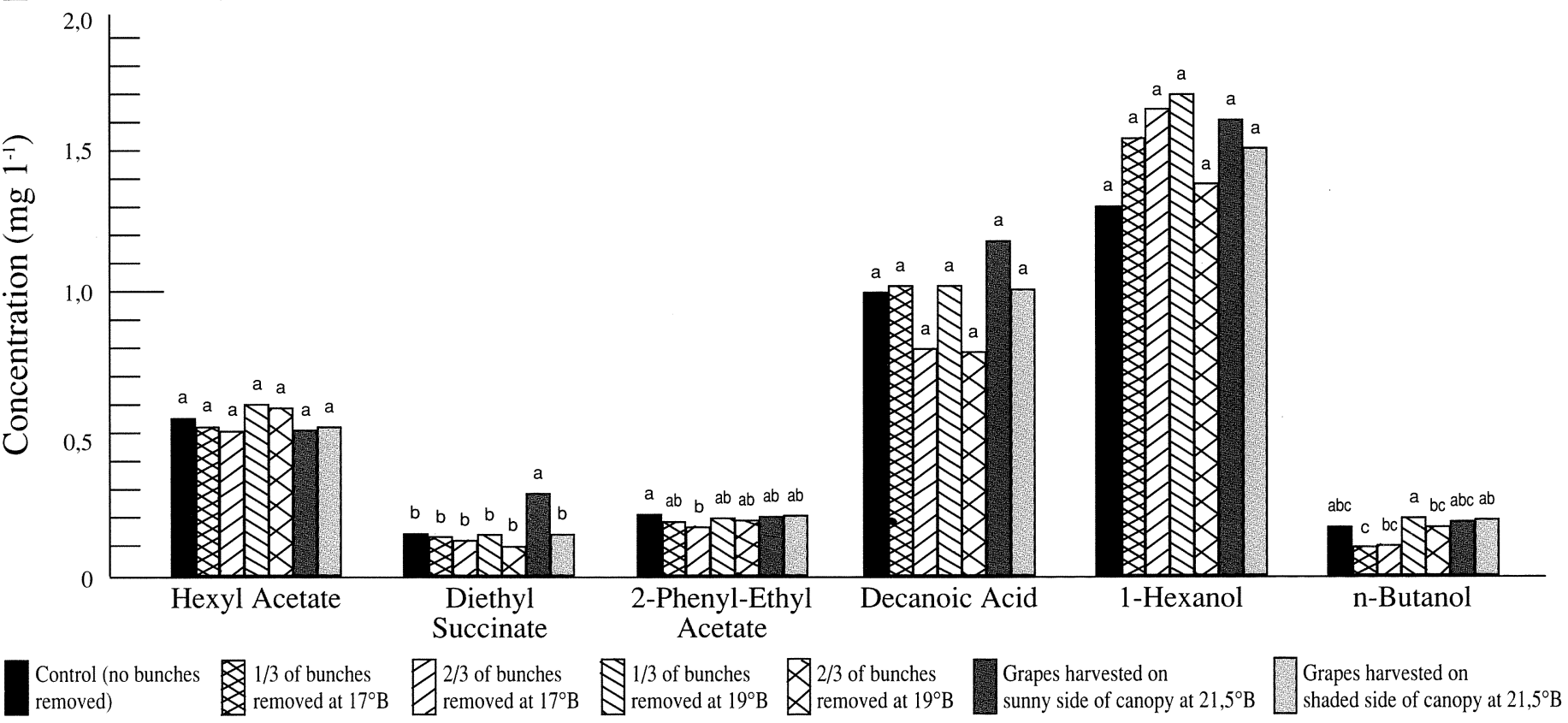

FIGURE 3

Mean effect of bunch removal on the concentration of individual volatile acid, alcohol and ester compounds in the wine of Chardonnay (clone CY 268) (1990-1993). Compounds with similar concentrations were grouped together. Bars of different labour measurements designated by the same letter do not differ for each labour measurement $(\mathrm{p} \leq 0,05)$. 


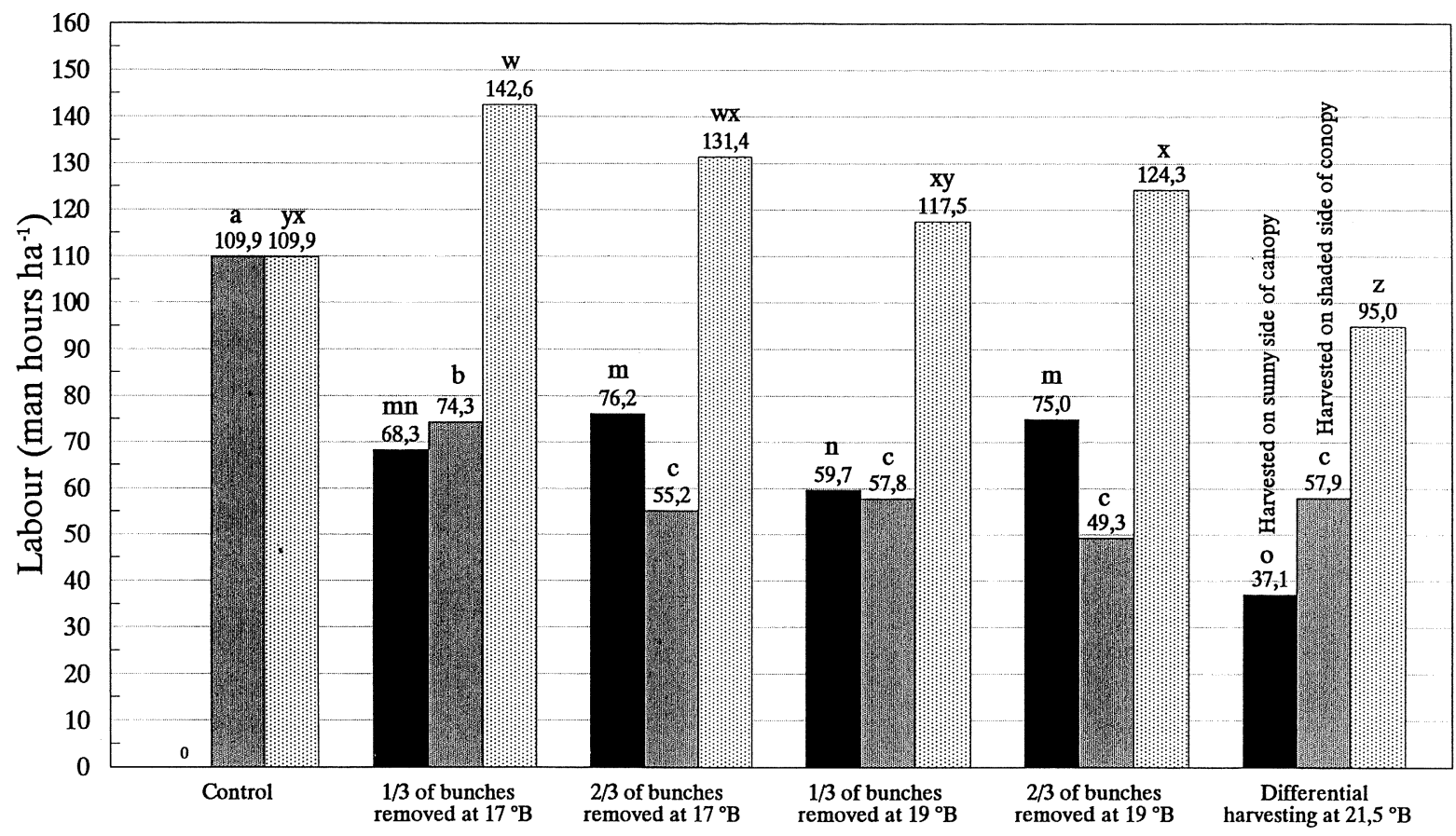

Degree and time of bunch removal

Labour to remove bunches $\square$ Labour to harvest Total labour for bunch removal and harvesting

\section{FIGURE 4}

Mean labour output to remove bunches during different stages of ripening and harvesting grapes of Chardonnay (clone CY 268) (1990-1993). Bars of different labour measurements designated by the same letter do not differ for each labour measurement $(\mathrm{p} \leq 0,05)$.

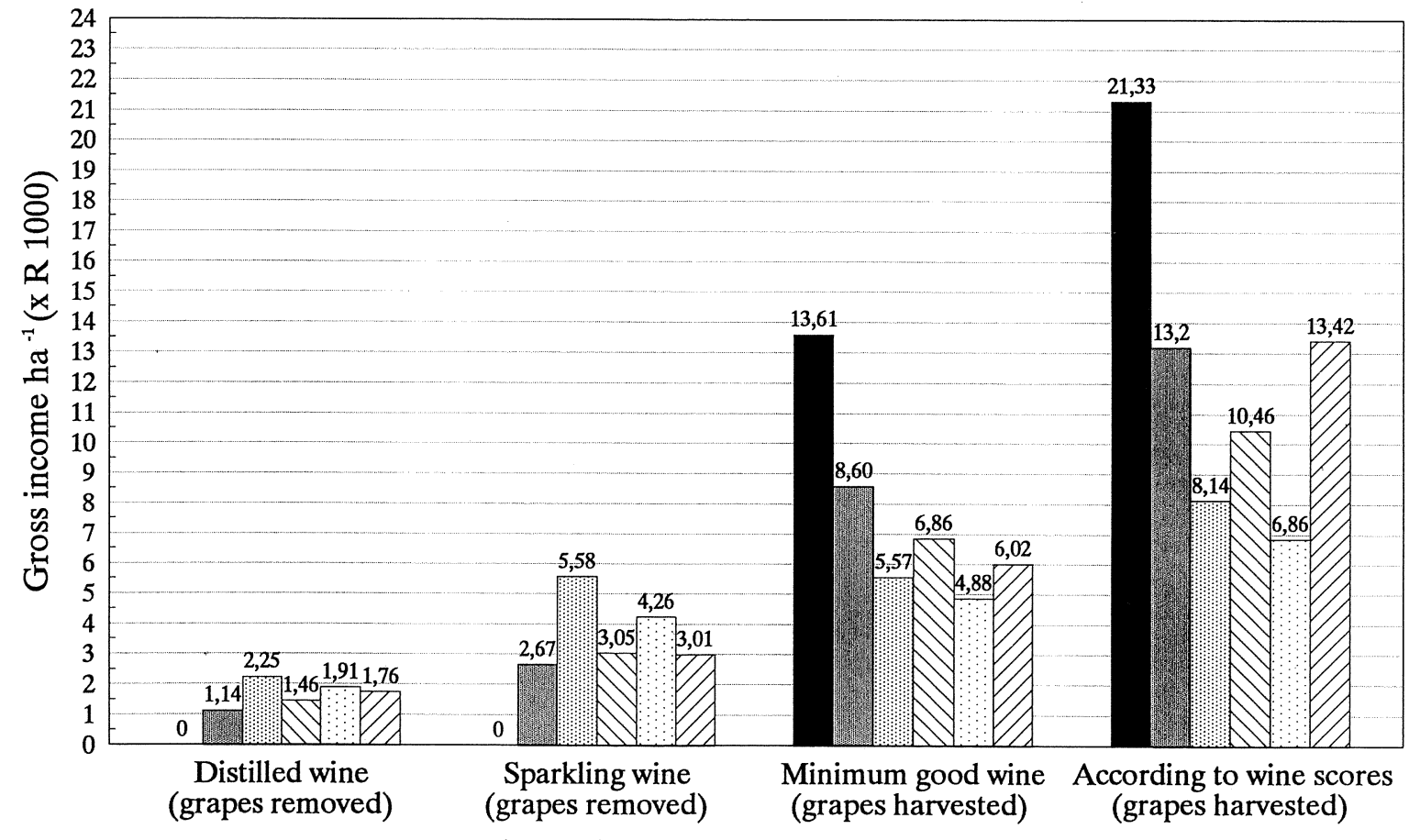

Theoretical gross income possibilities

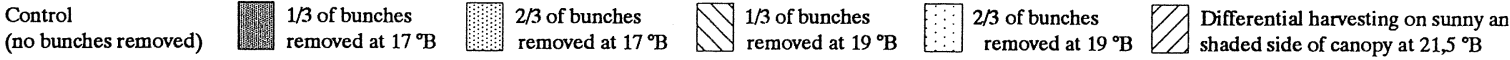

FIGURE 5

Mean gross income that could be generated from Chardonnay (clone CY 268) at Robertson, on the assumption that all the grapes be used economically and compensated for according to wine scores received (1990-1993). 


\section{CONCLUSIONS}

According to the cultivar guideline for Chardonnay in this region, yield was reduced to within the production level recommended by the wine industry $\left(8-12 \mathrm{t} \mathrm{ha}^{-1}\right)$ for wine category A (premium wines) when two thirds of the bunches were removed at $19^{\circ} \mathrm{B}$. However, since wine quality was not improved and production costs increased, bunch removal of Chardonnay cannot be recommended as an economically viable practice in the Robertson region under the conditions of the experiment. It can reasonably be assumed that Chardonnay will react similarly in other regions if bunch removal is applied under similar conditions.

The study indicated that bunch removal can only be recommended when vines are noticably stressed. In cases where bunch removal is necessary for reasons other than that, it would be more desirable if bunches can be removed at a reasonably late stage (e.g. $17^{\circ} \mathrm{B}$ or $19^{\circ} \mathrm{B}$ ) in order for removed grapes to be used in the making of other wine products. It is, however, not recommended that bunches be removed in high-yielding Chardonnay vineyards with a yield : cane mass ratio below 9-11, as was the case for the control vines, if sound pruning and canopy management practice are applied.

Under conditions of cultivar related naturally occurring overcropping, it might still be necessary to reduce the crop at an earlier stage to enable the vine to compensate physiologically during the rest of the season to be able to withstand stress conditions such as winter frost or severe drought in particularly dry land vineyards.

\section{LITERATURE CITED}

BAVARESCO, L. FRANCHINI, P. \& RUINI, S., 1991. Ulterior prove sul dirdamento dei grappoli e sulla crimatura dei germogli in alcuni vitigni del Veronese. Vignevini 18, 31-3.

BOOYSEN J.H., STEENKAMP, J. \& ARCHER, E., 1992. Benaming van vertikale prieelstelsels (met afkortings)/Namens of vertcal trellising systems (with abbreviations). Wynboer Tegnies 52, 15.

BRAVDO, B., HEPNER, Y LOINGER, C., COHEN, S. \& TABACMAN, H., 1984. Effect of crop level on growth, yield and wine quality of a highyielding Carignan vineyard. Am. J. Enol. Vitic. 35, 247-252

CARBONNEAU, A., LEClaiR, Ph., DUMARTIN, P., CORDEAU, J. \& ROUSSEL, C., 1977. Etude de $\ell$ 'influence chez la vigne du rapport partie vegetative/partie productive sur la production et la qualite des raisins. Connaiss, Vigne Vin. 11, 105-130.

CAWTHON, D.L., MORRIS, J.R. \& SIMS, C.A., 1984. Long-term effects of pruning severity, nodes per bearing unit, training systems and shoot positioning on the yield and quality of cultivar Concord grapes Vitis Labrusca. J. Am. Soc. Hortic. Sci. 109, 676-683.

FISHER, K.A., BRADT, O.A., WIBE, J. \& DIRKS, V.A., 1977. Cluster thinning "de Chaunac" French Hybrid grapes improves vine vigor and fruit quality in Ontario. J. Am. Soc. Hort Sci. 102, 162-165.

DI COLLALTO, G., FERRINI, F. \& BIRICOLTI, S., 1991. Risultati di ricerche sul diradamento dei grappoli della vite in ambiente collinare toscano Vignevini 18, 39-41.

GRIGOLLI, V., 1989. What are the results of grape thinning? Enotecnico 25, 107-111.
HUNTER, J.J. VISSER, J.H., \& DE VILLIERS, O.T., 1991. Preparation of grapes and extraction of sugars and organic acids for determination by highperformance liquid chromatography. Am. J. Enol. Vitic. 42, 237-244.

HUNTER, J.J., 1992. Loofbestuur vir 'n geil en verdigte wingerd. Wynboer Tegnies 49, 4-7.

HUNTER, J.J., RUFFNER, H.P., VOLSCHENK, C.G. \& LE ROUX, D.J., 1995. Partial defoliation of Vitis vinifera L. cv. Cabernet Sauvignon/99 Richer: Effect on root growth, canopy efficiency, grape composition, and wine quality. Am. J. Enol. Vitic. 46, 306-314.

KAPS, M.L. \& CAHOON, A., 1989. Berry thinning and cluster thinning influence vegetative growth, yield, fruit composition and net photosynthesis of Seyval blanc grapes. J. Am. Soc. Hortic. 114, 20-24.

KLIEWER, W.M., FREEMAN, B.M. \& HOSSOM, C., 1983. Effect of irrigation, crop level and potassium fertilization on Carignane vines. I. Degree of water stress and effect on growth and yield. Am. J. Enol. Vitic. 34, 186196.

LOONEY, N.E. \& WOOD, D.F., 1977. Some cluster thinning and gibberellic acid effects on fruit set, berry size, vine growth and yield of De Chaunac grapes. Can. J. Plant Sci. 57, 653-659.

LOONEY, N.E. 1981a. Some growth regulator and cluster thinning effects on berry set and size, berry quality, and annual productivity of de Chaunac grapes. Vitis. 20, 22-35.

LOONEY, N.E., 1981b. Grape cluster thinning stabilizes production, improves juice quality. The Goodfruit Grower. 32, 22.

LOTT, H \& EMIG, K.H., 1985. Ertragregulierung durch Ausdünnung von Trauben. Der Deutsche Weinbau. 40, 786-788.

MACVICAR., C.N. \& SOIL SURVEY STAFF, 1991. (2nd Ed.) Soil classification. A binomial system for South Africa. Directorate Agricultural information, Private Bag X144, 0001 Pretoria. Rep. of South Africa.

MARAIS, J. \& HOUTMAN, A.C., 1979. Quantitative gas chromatographic determination of specific esters and higher alcohols in wine using freon extraction. Am. J. Enol. Vitic. 30, 250-252.

MORANDO, Q.A., GERBI, V., MINATI, J.L., NOVELLO, V., EYNARD, I \& ARNULFO, C., 1991. Confronto tra interventi di diradamento e spuntatura dei grappoli all'allegagione e all'invaiature. Vignevini 18, 43-50.

MURISIER, F., JEANGROS, B. \& AERNY, J., 1986. Maîtrise du rendement et maturite du raisin. Essais 1985. Revue Suisse Vitic. Arboric, Hortic. 18, 297-310.

OUGH, C.S., \& NAGAOKA, R., 1984. Effect of cluster thinning and vineyard yields on grape and wine composition and wine quality of Cabernet Sauvignon. Am. J. Enol. Vitic. 35, 30-34.

PAYAN, J.J., CREUNET, B. \& ARCUSET, P., 1993. Mode de conduite: regulation de charge par suppression ou éclaircissage des grapes sur cepages meridionaux. Prog. Agric. et Vitic. 100, 489-494.

PETEGOLLI, D., 1991. Ricerche sul diradamento ormonico dei grapolli di vite. Vignevini 18, 21-24.

REYNOLDS, A.G., POOL, R.M. \& MATTICK, L.R., 1986. Effect of shoot density and crop control on growth, yield, fruit composition, and wine quality of Seyval blanc grapes. J. Amer. Soc. Hort. Sci. 111, 55-63.

REYNOLDS, A.G., 1989a. Impact of pruning strategy, cluster thinning, and shoot removal on growth, yield, and fruit composition of low-vigour De Chaunac vines. Can J. Plant Sci. 69, 269-275.

REYNOLDS, A.G., 1989b. "Riesling" grapes respond to cluster thinning and shoot density manipulation. J. Amer. Soc. Hort. Sci. 114, 364-368.

REYNOLDS, A.G., PRICE, S.F., WARDLE, D.A. \& WATSON, B.T., 1994. Fruit environment and crop level effects on Pinot noir. I. Vine performance and fruit composition in British Columbia. Am. J. Enol. Vitic. 45, 452-459.

SÉPULVEDA, R.G., MONDACA, G.O. \& ROJAS, P.N., 1984. Adelanto de maduracion y meioramiento de color de la uva cv. (I-III) Muscatel rosade. Investigacion Progreso Agropecuario la Platin 25, 8-13.

SIEGAL, S., 1959. Nonparametric statistics for the behavioural sciences. McGraw-Hill International book Company, Johannesburg.

SINTON, T.H., OUGH, C.S., KISSLER, J.J. \& KASIMATIS, A.N., 1978. Grape juice indicators for prediction of potential wine quality. I. Relation between crop level, juice and wine composition and wine sensory ratings and scores. Am. J. Enol. Vitic. 29, 267-271.

SMART, R.E., 1984. Canopy microclimate and effects in wine quality. T.H. Lee and Somers (eds.) Proc. Eust, Wine Res. Inst. November 1983, Perth, Australia, 113-132. 
SMART, R.E., DICK, J.K., GRAVETT, I.M. \& FISHER, B.M., 1990. Canopy management improves grape yield and wine quality - Principles and Practices. S. Afr. J. Enol. Vitic. 11, 3-17.

TROMP, A. \& CONRADIE, W.J., 1979. An effective scoring system for the sensory evaluation of experimental wines. Amer. J. Enol. Vitic. 30, 278283.

UBIGLI, M., 1991. Valutazione sperimentale delle influenze del diradamento dei grapolli sulla qualità del vino Barbera. Vignevini 18, 57-61.

VALENTINI, L., BRANCADORO, L., MATROMAURO, F.,BOGONI, M., FAILLA, O., GIONGO, A., BOGONI, M. \& SCIENZA, A., 1991. Il controllo della maturazione dell'uva di Chardonny e Riesling renano in Oltrepo Pavese ottenuto attraverso il diradamento dei grappoli. Vignevini 18, 36-38.

VAN SCHALWYCK, D \& DE VILLIERS, F.S., 1992a. Die effek van graad en tyd van trosvermindering op die druif-en wyngehalte van Cabernet Sauvignon, Bukettraube en Feraõ Pires - 'n gevalle studie. Wynboer Tegnies 48, 9-11.

VAN SCHALKWYK, D. \& DE VILLIERS, F.S., 1992b. Die invloed van oesvermindering tydens verskillende fenologiese stadiums op die winderden wynprestasie van Fernaõ Pires. Wynboer Tegnies 50, 14-16.
VAN SCHALKWYK, D. \& DE VILLIERS, F.E. \& FOUCHÉ, G.W., 1996. Wanneer moet trosvermindering by wyndruiwe toegepas word. Wynboer Tegnies 78, 5-17.

VOS, P.J.A., ZEEMAN, W. \& HEYMANN, H., 1978. The effect on wine quality of diammonium phosphate additions to must. Proc. S. Afr. Soc. Enol. Vitic. 87-104.

WOLPERT, J.A., HOWELL, G.S. \& MANSFIELD, T.K., 1983. Sampling Vidal blanc grapes. I. Effect of training system, pruning severity, shoot exposure, shoot origin and cluster thinning on cluster weight and fruit quality. Am. J. Enol. Vitic. 84, 72-76.

ZAMBONI, M., FRANSCHINI, P. \& BAVERESCO, L., 1991. Primi resutati sul diradamento manuale e chimico del Barbera nel Piacentino. Vignevini. 18, 25-30.

ZIRONI, R., BUIATTI, S., CELOTTI, E. \& AMATI, A., 1983. Study on periodical harvesting of grapes. Note II: Composition of low-alcohol beverages and wines. Wein-Wissen. 48, 9-14. 